\title{
Discussion on the Curriculum System of "Modern Apprenticeship" Educational Model in Accounting Major of Higher Vocational Colleges
}

\author{
Yiman Song \\ Department of Finance and Economics \\ Nanchong Vocational and Technical College \\ Nanchong, China
}

\begin{abstract}
Based on the "Opinions on the implementation of pilot Work of Modern Apprenticeship" issued by the Ministry of Education of China, this paper analyzes the effectiveness of curriculum reform under the "modern apprenticeship" education model for the curriculum of accounting major in higher vocational colleges. That is how to make vocational colleges, enterprises, government, and students achieve a four win situation. This paper first elaborates the necessity and meaning of studying the "modern apprenticeship" educational model. Then it briefly introduces the research situation of "modern apprenticeship" both at home and abroad and the influence of the "modern apprenticeship" educational model on higher vocational education. Besides, this paper analyzes the problems in the curriculum system of accounting major in higher vocational colleges under the current mode of cooperation between colleges and enterprises. Finally, the innovative advantages of the curriculum system optimization made by accounting major of higher vocational colleges by applying the "modern apprenticeship" education mode is presented and the outlook for development prospects of higher vocational colleges under this mode is put forward.
\end{abstract}

Keywords-higher vocational colleges; modern apprenticeship; accounting major; curriculum

\section{INTRODUCTION}

In September 2014, the Ministry of Education issued the Opinions on the implementation of the pilot work of Modern Apprenticeship, which states that the modern apprenticeship system should realize the consistency of curriculum and industry demand, course content and professional standards, teaching process and production process, certificate and vocational qualification certificate, and vocational education and lifelong learning, to improve the quality of personnel training and its pertinence. With the accelerated economic transformation and the upgrading of industrial structure, social and economic environment in China has undergone great changes. Requirements of society and enterprises for the quality of accounting professionals and professional skills are more and more precise. According to the employment Blue Book published by the MyCOS Research Institute in 2017, the employment rate of the graduates of accounting major is $92.5 \%$ and the relevancy between the job and major of graduates of accounting major after six months after graduation is $82 \%$, but the quits rate within six months is quite high. The reason is because companies believe that the professional ability of graduates is much lower than the level of job requirements. This shows that the current curriculum system of accounting major in higher vocational colleges does not meet the demand for talents of the society. Therefore, how to cultivate the high-quality applied accounting talents with sustainable competitiveness needed by enterprises is the problem that needs to be solved by national vocational education management department and higher vocational colleges. "Modern apprenticeship" education model comes into being.

\section{CONCEPT AND CONNOTATION OF MODERN APPRENTICESHIP}

"Modern apprenticeship" refers to the education model promoted by enterprises and schools together. Its education object includes both students and employees. For them, school attendance is employment. Part of their time is spent on the production in enterprises and part of the time is spent in school. Therefore, students are the same to employees who can receive the corresponding wages from the enterprise.

In modern apprenticeship, teachers and masters are the double support forces, occupying the equally important position. They can directly impart the skills to students, and have an important impact on the professional ethics of students; curriculum system is the cornerstone of the implementation of this model as well as the link maintaining the bind of school teachers and maters of enterprises, which guides the direction of personnel training and determine the quality and level of personnel training to a large extent. "Modern apprenticeship" takes students as the main body of cultivation, and its fundamental starting point is to improve the quality of student training through the deep-level cooperation of schools and enterprises to meet the requirements of enterprises for talents, so as to achieve the goal of win-win between students, schools, enterprises, and government. 


\section{RESEARCH SITUATION OF "MODERN} APPRENTICESHIP" AT HOME AND ABROAD AND THE INFLUENCE OF "MODERN APPRENTICESHIP" EDUCATION MODEL ON HIGHER VOCATIONAL EDUCATION

Compared with the traditional apprenticeship system, students do not need to worry about finding a job after graduation, because they have a dual identity. They have signed an employment contract with the enterprise since entering the school, and thus become a student at the same time as an employee of enterprises. Compared with ordinary employees, they have the double process of learning theoretical knowledge in school and learning from the master. For the students of higher vocational college who are cultivated by the modern apprenticeship education model, during the three years of university, they will travel between enterprises and schools.

\section{A. Research Situation of Modern Apprenticeship at Home and Abroad}

The term "apprenticeship" began to be used since the late 13th century in the United Kingdom. The word "apprenticeship" was used in the 1261 by British harness line in London. The literature of "apprenticeship" first appeared in 1957 in China, which is in "Good New Apprentice System" published by Su Qiufu's in the Journal of Labor. The earliest literature on the study of "modern apprenticeship" appeared in the "British Modern Apprenticeship" of He Xiaoyu in the journal "China Training" in 2001. A total of 56 literatures were searched on the theme of "modern apprenticeship of accounting major" in "Chinese Journal Full-text Database" and "Master's Degree Thesis Database". All the literatures were searched in the "Chinese Journal Full-text Database" taking "Modern Apprenticeship curriculum of accounting major of higher vocational school", and 5 articles were found. The earliest one is Research on the Development of Dual-course System of school and enterprises of Accounting Major in Higher Vocational Education under Modern Apprenticeship" of Ouyang Bin in the "Journal of Hubei Adult Education College" in 2015, and the other four are newly published in 2016 and 2017. 3992 pieces of literature on the theme of "apprenticeship" are found in the "foreign literature database", and 162 pieces of literature on the theme of "modern apprenticeship" are found. No literature on the theme of "modern apprenticeship of accounting major in Higher Vocational College".

It can be seen from the above data that there are very few study materials on the "modern apprenticeship" curriculum system of accounting major of higher vocational colleges at home and abroad, and the research on the curriculum system of accounting major in higher vocational colleges is also a new topic in China that is made over the past two years.

\section{B. The Influence of "Modern Apprenticeship" Education Model in China on Higher Vocational Education}

"Modern apprenticeship" is the requirement of vocational education actively serving the current economic and social development, which can promote the interactive development of vocational education system and labor employment system, open up and broaden the channel of training and growth of technical and skillful talents. It is also the strategic choice of promoting the construction of modern vocational education system, the effective way of deepening the interaction of production and teaching and cooperation of school and enterprise and promoting the combination of work and study and knowledge and practice, as well as the major breakthrough to cultivate the talents demanded by new type of society with high competency, high quality and high skill, social responsibility, creative spirit and practice ability.

\section{PROBlEMS IN THE CURRICULUM OF ACCOUNTING \\ MAJOR IN HIGHER VOCATIONAL COLLEGES UNDER THE CURRENT Mode of COOPERATION BETWEEN COLLEGES AND ENTERPRISES}

\section{A. Unreasonable Ratio of Course Module}

At present, the accounting major of higher vocational colleges adopts the credit system in curriculum. The credit system is taking the credits set for each course as the unit to calculate the student's learning. In general, the number of classes per week of one subject is its credit hour. For example, the class period of accounting basic courses is generally 1-16 weeks, with 5 times per week, so the credit of this class is 5 points. According to this credit, the college requires students to get at least a certain credit before graduation. This system is derived in Harvard University in the United States, which is introduced into higher education schools in China by the Peking University President Cai Yuanpei.

Accounting major of higher vocational college also use the credit system. There are differences in setting of credit between different colleges according to their own situation and the demand for talent of the region, but most of the credit of accounting major of higher vocational college is generally set at 125 credits -150 credits, which includes the modules compulsory courses, elective courses and practical teaching. From the curriculum setting of most accounting majors of higher vocational colleges, it can be seen that compulsory classes account for between $45 \%-60 \%$, elective courses account for about $20 \%$, and practical training is very little. Through the visit to the employers, it is found that when graduates of accounting majors firstly encounter the real account check of employers, the professional thinking and practical ability of students is far from enough, which shows that the curriculum module of school is unreasonable while the proportion of practical training is far enough, leading to the lack of actual operation ability of students.

\section{B. There are Differences between the Requirements of the Enterprise for Talents and the Curriculum}

It can be seen in the major recruitment website that enterprises no longer regard the education background as the only criterion in the recruitment of accounting staff, but lay more emphasis on the candidate's work experience. Accounting work includes practical work and theoretical work, while all enterprises need accounting staff to do calculation work, which focus on practice, so companies 
prefer the accountant with more working experience, so that they can work immediately after entering the company, which can save the company's training costs. Through research it is found that in the recruitment, enterprises will consider to recruit fresh graduates for jobs of less technical requirements. Most companies believe that accounting is a technical and practical work, so they pay more attention to the experience and practical ability of candidates. Enterprises hold that the current accounting graduates lack practical experience in the actual work, so they can't solve the problems actively and excellently. This is related to the too little proportion of the practical teaching in curriculum of accounting majors of most of higher vocational colleges. From the specific practice course, it can be seen that the practical teaching links mainly include the following courses: accounting basic training, basic skills training for accounting, cost accounting training, financial management training, accounting pre-job training and son on. Basically, in higher vocational colleges, teaching of this part of the courses is completed by students under the guidance of school teachers. The so-called combination of work and study and social practice links are the link that students can learn real practice in the enterprises, but this link only account for less than $10 \%$ in the practical teaching, and only accounts for $1 \%$ of the total credit setting in the entire curriculum system. Therefore, there is a big difference between the requirements of the enterprise for talents and the curriculum setting of colleges, which is the important reason why graduates can't meet the requirements of the enterprise for accounting personnel.

\section{THE REFORM OF CURRICULUM DESIGN FOR} ACCOUNTING MAJOR IN Higher VOCATIONAL COLLEGE UNDER THE "MODERN APPRENTICESHIP" EDUCATION MODE

\section{A. The Important Role of Enterprises in the Curriculum of Modern Apprenticeship}

According to the data of major recruitment website, for accounting talent, almost all of the enterprises will give priority to the candidates with 2-3 years of work experience. Work experience for fresh graduates is corresponding to the ability of actual operation, which not only requires students of accounting major of higher vocational college to have excellent professional theoretical foundation, but also demand them to independently finish the work from filling the voucher to the registration of books or even the preparation of statements, so that enterprises do not need to input training time and economic costs.

Many students studying in higher vocational colleges are relatively weak in learning habits, learning methods and ability of self-discipline, but they are strong in practical ability. In view of this characteristic of students, "modern apprenticeship" requires enterprises to play an important role in talent cultivation, and deeply participate in personnel training. Enterprises and schools should share the responsibility of teaching and evaluation of the apprenticeship. They need to participate jointly and develop relevant teaching plans, curriculum systems and assessment criteria.
In deepening the school and enterprise, they should implement the modern type of apprenticeship education model of "enrollment is the recruitment, admission to the school is to the enterprise, teachers from the school and enterprise jointly cultivate" to encourage higher vocational colleges and enterprises together carry out apprenticeship education and speed up the training of young skillful talents. Curriculum of "modern apprenticeship" regards the employment needs of enterprises and job qualification standards as the service goal. And schools sign the labor contract for three years between student and enterprises and the cooperation agreements of jointly cultivation of schools and enterprises.

\section{B. Curriculum Reform under the "Modern Apprenticeship"}

In view of the requirements of various enterprises in the society for accounting talents, the higher vocational colleges should analyze the skills needed for the position, and then reform the existing curriculum based on them. Of course, requirements for talent of the same job are different in different regions or different enterprises, so it is necessary to first find the differences, and then according to the differences remove the courses that aren't needed by jobs such as marketing, and personal finance, of which the knowledge is unnecessary for their jobs and meaningless for the formation of their post capacity.

In order to meet the requirements of the enterprises for post ability of talents, it can be decomposed into several parts. Then courses directly related to these abilities are determined to form the knowledge base for cultivating these abilities, so as to construct the general framework of the curriculum system. Second, according to the principle of matching the posts capacity and knowledge, the specific setting of each course is determined in order to enrich the already formed curriculum system framework. Third, schools should set the courses that improving the correct outlook on life, values, and humanistic cultivation that is needed for engaging in social work as public courses, to penetrate into the professional ethics education of accounting professional training. Finally, other courses related to the major or popular industry knowledge should be set as elective courses, which on the one hand can expand the student's vision, and on the other hand can increase the pertinence in the recruitment of various industries, laying the foundation for the choice of the post of students after stepping into the society.

This kind of curriculum according to the analysis of the requirement for posts capacity of talents can not only make the cultivation of students' ability fit for needs of enterprises, but also reduce the waste of school resources and students' energy to realize the optimization of resources.

The specific operating procedure is: enterprises directly employ the "apprentice" from the accounting major of the higher vocational college they cooperate with, so that in the three years of their study, about two-thirds of the time is used for training and career-oriented study through the way of "master of enterprise guiding the apprentice", and the other one-third of the time are spent in college in learning the 
necessary cultural and professional theoretical knowledge. After three years, these "apprentices" can both get the accounting professional qualification certificate or assistant accountant qualification certificate and academic certificate of higher vocational education. The deep cooperation between school enterprise not only cultivate a highly skilled applied talent, but also save the training costs of enterprises, create a profit, and cultivate the recognition of corporation culture and the sense of belonging to the enterprise of the "apprentice".

\section{CONCLUSION}

Education, especially vocational education serves for the national economy and social development. Nearly $80 \%$ of new labor forces every year are from the training system of technologic person. "Decision of the State Council on speeding up the development of modern vocational education" (Guo Fa [2014] 19) provides a good opportunity for higher vocational colleges to deepen the cooperation between school and enterprise and carrying out the development of "modern apprenticeship" education model.

The employment of graduates of higher vocational colleges is related to economic upgrading, improvement of people's livelihood and social stability. The employment rate of students in higher vocational colleges is the key to the long-term development of the school. When students fill the application form, the professional curriculum design and employment rate are the main factors of their consideration, while when enterprises choose the talents, the level of vocational skills is the primary condition of their consideration. Higher vocational colleges reform the curriculum of accounting major by using "modern apprenticeship" teaching model, which not only meets the requirements of the national development for vocational education, but also can effectively attract students and cultivate the talents needed by enterprises. This also is conducive to the long-term survival and development of the colleges, thus achieving the four win situation of government, enterprises, college and student.

\section{REFERENCES}

[1] Jim Campbell,Ailsa Mckay,Emily Thomson. How 'modern' is the modern apprenticeship? [J]. Local Economy,2005,20(3).

[2] CHRIS MINNS,PATRICK WALLIS. Rules and reality: quantifying the practice of apprenticeship in early modern England1[J]. The Economic History Review,2012,65(2).

[3] Howard Gospel,Alison Fuller. The modern apprenticeship: new wine in old bottles? [J]. Human Resource Management Journal,2006,8(1):

[4] Wang Boqing, Zhou Lingbo. Employment report Report of Higher Vocational Education in China in 2017. social sciences academic press, 2017. 06

[5] Lu Xingfeng, Xue Chunyan, Liu Fang. A Probe into the Teaching of "Dual - guide" major courses under the Modern Apprenticeship Taking Accounting major of Higher Vocational colleges as an Example. Estate and Science Tribune, 2017, 16(19): 202-204.

[6] Ouyang Bin. Research on the Development of Dual - course System of Accounting Major in Higher Vocational Education under Modern Apprenticeship. Journal of Hubei Adult Education Institute, 2015,21(04): 36-39. [2017-10-10]. DOI : 10.16019/j.cnki.cn42$1578 / \mathrm{g} 4.2015 .04 .010$
[7] Ma Lei. Reconstruction of Curriculum System of Accounting Major in Higher Vocational Education under the Mode of Modern Apprenticeship. Career Horizon, 2016, 12(04): 21-23.

[8] Han Yuzhu. A Study on the Curriculum System of Computerized Accounting Program in Higher Vocational Education under the Modern Apprenticeship System. Manage' Journal, 2016,(33): 416.

[9] Shao Jinghao. The Reform of examination of Accounting Curriculum in Higher Vocational Education under the Modern Apprenticeship. Labor Security World, 2016, (26): 51+53.

[10] Wang Hongjie, Ma Huaili. A Study on Modern Apprenticeship Model of Accounting Major Higher Vocational Education in Xinjiang. CO-Oerativeconomy \& Science, 2016, (02): 118-119.

[11] Cao Yi. A Study on the Application of Agency Accounting in Modern Apprenticeship of Accounting Major in Higher Vocational Education. Education Science Forum | Education Sci Forum, 2017, (18): 59-62. 